\title{
Benign Intraocular Medulloepithelioma
}

National Cancer Institute

\section{Source}

National Cancer Institute. Benign Intraocular Medulloepithelioma. NCI Thesaurus. Code C66807.

A rare, unilateral, benign embryonic neoplasm typically presenting as a cilliary body mass during childhood. It is composed of medullary epithelial cells. 